Payment systems to facilitate South Asian integration

Ashima Goyal

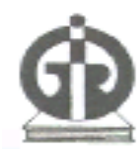

Indira Gandhi Institute of Development Research, Mumbai July 2015

http://www.igidr.ac.in/pdf/publication/WP-2015-021.pdf 


\title{
Payment systems to facilitate South Asian integration
}

\author{
Ashima Goyal \\ Indira Gandhi Institute of Development Research (IGIDR) \\ General Arun Kumar Vaidya Marg \\ Goregaon (E), Mumbai- 400065, INDIA \\ Email(corresponding author): ashima@igidr.ac.in
}

\begin{abstract}
Considerable technology-based evolution in payment systems offers opportunities for convergence to a regional payment system. Though South Asian wholesale payment systems are more developed compared to retail, and smaller countries still lag behind, the South Asian Association for Regional Cooperation Payment Council offers a forum to facilitate convergence. The existing Asian Clearing Union can also be revitalized using developments in payment systems. Changes include faster settlement using real time flow through the system backed by local liquidity encouraging local currency use, reduction in transaction costs and delays, expansion of facilities offered, types of flows allowed, and number of participants. Invoicing in local currencies reduces pass through of changes in exchange rates, and hence lowers their inflationary impact. Electronic systems can discriminate between types of flows and provide detailed information without procedural delays, reducing security concerns.
\end{abstract}

Keywords: Payment systems, South Asia, integration, Asian Clearing Union

JEL Code: F36, F42, F55

\section{Acknowledgements:}

This paper is an abbreviated version of a UNESCAP report and working paper 14032, and is based on a presentation made at the 7th South Asia Summit 2014. I am grateful to Nagesh Kumar and Pabir De for the invitation, and thank without implicating seminar participants and S. K. Bal, K.C. Chakrabarty, Subir Gokarn, Shyamala Gopinath, G. Mahalingam, G. Padmanabhan and Vijay Singh Shekhawat for useful inputs, two anonymous UNESCAP referees for helpful comments, Sanchit Arora, Vaishnavi and Reshma Aguiar for assistance. 


\section{Payment systems to facilitate South Asian integration}

\section{INTRODUCTION}

The paper examines the role payment systems can play in greater South Asian integration, including intra-regional trade facilitation. As payment systems become more sophisticated and their capabilities converge in the region, they can more actively facilitate trade. More focus on regional interactions as a route towards greater regional prosperity makes the issue relevant.

Most countries now have real time gross settlement with capabilities for settlement in multiple currencies. But these are still unused and smaller countries lag. South Asia had the benefit of a special payments institution set-up to help regional trade - the Asian Clearing Union (ACU). But its potential contributions rise if its functions and transactions are expanded using modern payment systems. The Board has the power to do this. Concerns about security, sources and types of flows are not an issue. Modern payment systems allow finer restrictions to be imposed, as required, without raising transaction costs. Regional clearing can reduce time delays and costs associated with using clearing banks based in the Western hemisphere.

Post crisis dollar volatility and shortage have revived interest in arrangements that will give some independence from the dollar, and from US regulatory regimes, while reducing the dollar financing required for current account deficits. More competition and diversity in payment mechanisms will improve the stability of the global financial system.

The rest of the paper is as follows: Section II analyzes recent developments in payment systems; Section III presents a brief background of the ACU; Section IV discusses potential improvements; before Section V concludes.

\section{PAYMENT SYSTEMS}

A payment system is the set of infrastructure, institutions, laws, standards, and operating procedures underlying the discharge of financial obligations between parties (Saqib and Al-Jabri, 2011; World Bank, 2010; BIS, 2001; Khiaonarog, 2000; Haldane 
et al. 2008). Since the seventies, payment systems have been changing around the world. The prime driver is technology, which has enabled innovations converting manual transactions to electronic, saving time, costs, and reducing errors. A second reason is liberalization and global market integration requiring more robust and standardized processes.

There are three main areas of change. First is the shift to electronic cheque clearing; second systems such as automatic clearing house $(\mathrm{ACH})$ underlying small value or retail transfers such as point of sale for credit/ debit cards and bank automatic teller machines; third Real Time Gross Settlement (RTGS) systems for wholesale or large value transfers. A key element of all three is central electronic clearing and settlement, removing the need for multiple transactions, while facilitating the use of modern payment systems, delivery mechanisms and multiple currencies.

RTGS settles large value inter-bank and other time-critical customer payments in gross terms. That is, the central bank (CB) account of the remitting bank is debited and that of the receiving bank is credited. A final and irrevocable settlement is made in real time, as it occurs, thus removing settlement and operating risk. RTGS provides other services such as electronic payment messaging replacing the use of cheques. The central bank mediation also reduces systemic and credit risk. Real time settlement reduces market and liquidity risk since there is no change in market values between the transaction and the settlement time. But since banks need to settle continuously, they require assured access to short-term liquidity. RTGS also enables end of the day net settlement of small value items. This type of net settlement used to be the norm earlier for all items.

By 1996 RTGS was already in use in the G-10 countries and even in some emerging markets like Hong Kong, Korea and Thailand, and it was adopted rapidly over the next decade. There was continuous improvement in messaging standards and other aspects, allowing late adopters such as emerging markets (EMs), to leapfrog to best market practices.

Reducing transaction costs confers an externality, which individual players do not internalize, so $\mathrm{CBs}$ have driven the change around the world. Moreover, their 
responsibility for financial stability, and as liquidity providers of the last resort, makes them natural developers and supervisors of payment systems. BIS (2001) core principles for payment systems underline these roles of central banks, as well as that of international cooperation, including open universal standards. A large number of complementary changes are therefore required. Legal systems for payment systems have to be strengthened and consumer protection and competition issues have to be covered.

ACH credit transfers include payroll, social security, and tax refunds. Utility bills are examples of $\mathrm{ACH}$ debit transfers from one account to many accounts. In an ideal payment system, $\mathrm{ACH}$ is expected to cover 90 per cent of the total volume and 10 per cent of the value while RTGS covers the rest. But in 2012-13 small transfers in India were only 75 per cent of transactions in volume terms and 6.3 per cent in value. This shows the comparative under-development of retail payments. Moreover, in advanced economies (AEs) payment systems work with other currencies. Parts are privatized giving the private sector a role.

India, Pakistan, Sri Lanka and Maldives have implemented RTGS systems in addition to retail payments systems, and Electronic Cheque Clearing (ECC). Other countries of the group have ECC, retail payments and end-day or points during the day net settlements system such as national electronic fund transfer (NEFT) for large value payments. Bangladesh has focused relatively more on retail systems. The World Bank (2010) Payments Survey characterized Pakistan, Sri Lanka and Nepal as RTGS plus cheque clearinghouse, compared to AEs with only RTGS. Retail development of payment systems is also limited in the South Asian region.

There are initiatives for regional convergence. The South Asian Association for Regional Cooperation (SAARC) Payment Council offers a forum for regular interaction and learning ${ }^{1}$. For those not having RTGS systems, the most economically viable solution is to implement one automated integrated system. All South Asian

\footnotetext{
${ }^{1}$ See http://www.sbp.org.pk/Saarc/Publications/Matrix/PSMatrix.pdf for a detailed item-wise comparison of 2013 payment systems in the Saarc countries. A regional network of Saarc Central Bank Governors and Finance Secretaries, Saarc finance, was established on 9 September 1998. It meets biannually at the time of IMF/WB meetings. It launched a Saarc Payment Council (SPC) in 2008 with the aim of bringing about convergence in regional payment systems. See http://www.sbp.org.pk/Saarc/Roadmap.htm
} 
countries need to further develop their retail payment infrastructure, since the use of electronic payments instruments (such as payment cards and debit and credit transfers) is low compared to other EMs.

\section{II.1. Regional Payment Systems}

There is constant international innovation and improvement in payments and settlement systems that South Asia can draw upon. Many initiatives ${ }^{2}$ aim to strengthen and standardize payments and securities systems and build institutional capacity in developing countries.

Of these, the Southern African Development Community (SADC) initiative, started in 1996 with the assistance of the IMF, World Bank and the BIS, took the first step to implementing a common electronic cross-border payment system across all member states of the SADC regional economic community on 22 July 2013 when the Integrated Regional Electronic Settlement System became operational in the four countries of the Common Monetary Area (CMA): South Africa, Namibia, Lesotho and Swaziland. Differing sizes and levels of economic and political influence, and overlapping membership in different regional groupings of SADC members are challenges for integration. Despite delays in achieving monetary targets, the CMA pilot was undertaken rather than indefinitely postpone the implementation of the SADC Payment Integration System. The South African Reserve Bank led the process.

Monetary integration requires stable domestic financial systems in the region as a prerequisite. Most of the trade benefits come from integrating payment and settlement systems even without reaching a full monetary union. Second, a settlement bank is required for the region, to enable faster transfer and receipt of funds at a lower price and with reduced risk. The Central Bank of Mauritius is the settlement bank of the Regional Payment and Settlement System (REPSS) of the Common Market for Eastern and Southern Africa, which began operations in October 2012. In the REPSS business model, commercial banks play a reduced role compared to central banks.

\footnotetext{
${ }^{2}$ See

http://siteresources.worldbank.org/INTMNAREGTOPPOVRED/Resources/MENAFlagshipPaymentsa ndSettlementsSystems12_20_10.pdf; http://www.saiia.org.za/doc_download/447-perisa-case-study-2private-sector-sadc-payment-integration-system
} 
Regional cross-border payments require co-ordination in trade, monetary and foreignexchange control policy.

Cross border payments involve settlement of FX transactions, which give rise to credit risk, principal risk, liquidity risk and legal risk. Settlement is normally in the payment versus payment $(\mathrm{PvP})$ mode. Each FX trade involves two payment delivery legsfirst, in the domestic currency and second in foreign currency. Without payment of the domestic currency conditional on its final receipt of the foreign currency it bought, a bank can lose the full principal value of a transaction. Temporary delays in settlement expose a receiving bank to liquidity risk since unsettled funds may be needed to meet other obligations. Legal risks can arise since settlement involves more than one jurisdiction. Most banks need an intermediary institution to settle the foreign currency leg outside their country of incorporation. The CLS Bank, set up by a number of AEs, provides the largest multi-currency cash settlement system for 17 currencies.

Cross-border integration of regional payment systems can improve settlement efficiency and safety of cross-border payments while providing competition for mainstream alternatives that have come to dominate especially in EMs. For example, a rising proportion of commercial banks (90 per cent in 2008 up from 78 per cent in 2006) use the Society for Worldwide Interbank Financial Telecommunication (SWIFT) network for cross-border funds transfers, but the share was 100 per cent in low income countries, including the South Asian region. SWIFT Service Bureaus were alternatives that smaller financial institutions used to access the SWIFT network, in many cases through the central bank. While use of these is falling everywhere the fall is especially sharp in low income countries, from $57 \%$ to only $22 \%$ in 2008 (World Bank 2010). CBs have to again take a leadership role, which they have ceded, especially in EMs, to private players. Some of the regional initiatives are reversing this.

The World Bank survey showed that in 200859 countries had established links for cross-border settlement, while another 21 expected to establish such links within two years. All EU member countries have such links since a Single Euro Payments Area (SEPA) harmonizes the making and processing of euro payments, although this does not involve multiple currencies. Customers can make cashless euro payments, using a 
single payment account and a single set of payment instruments to anyone located anywhere in Europe although this is a single currency system. The ECB's powerful Target 2 RTGS covers all of the Eurozone, unifying government securities markets.

There is considerable innovation in non-bank payment services, with Google and Apple stepping into the fray, although most of these payment innovations continue to be in partnership with banks. Real time services are reaching retail levels. So EMs follow a moving target. Even so many EM banks have the potential late comer advantage in adopting cheaper new generation technologies compared to large Western banks locked into now less efficient systems they had often developed themselves ${ }^{3}$.

The South Asian region also has the advantage of a regional payment mechanism functioning, although at a low level and only for trade transactions, since the 1970s. But it offers a base, and a history of interaction, that could be built upon using recent developments in payment systems. The integration of European payment systems also started with a European payment clearing union.

\section{ASIAN CLEARING UNION: HISTORY AND FUNCTIONING}

The Asian Clearing Union (ACU) was established in December 1974 with help from the United Nations Economic and Social Commission for Asia and the Pacific (UNESCAP). Headquarters are at Tehran, Iran. In 2014 the other members of ACU were the central banks of Bangladesh, Bhutan, India, Maldives, Nepal, Pakistan, Sri Lanka, and Myanmar. It was set-up to help countries deal with an acute shortage of foreign exchange by providing a system for clearing payments among the member countries on a multilateral basis ${ }^{4}$. ACU governance mechanisms worked smoothly, ensuring no country ever defaulted.

\footnotetext{
${ }^{3}$ The UK and European payment systems are much faster than those of the US, where banks still rely on cheques. The Fed does not have the power to force change, which banks resist since they fear loss of revenue on wire charges (see http://www.ft.com/intl/cms/s/0/03a1f4b0-06d3-11e4-ba3200144feab7de.html?siteedition=intl\#axzz3617fOQqu).

${ }^{4}$ Some ACU related websites are: http://www.asianclearingunion.org; http://www.rma.org.bt/EXTERNALWEB/admin/ACU\%20awareness\%20materials.pdf; http://www.rbi.org.in/scripts/FAQView.aspx?Id=50; other data sources include ACU Annual Reports, various years; IMF, International Financial Statistics, various issues; relevant RBI circulars such as: (RBI, 2010); http://rbi.org.in/scripts/BS ViewMasCirculardetails.aspx?id=7354\#b.
} 
The advantage of multilateral over bilateral clearing is that if country $\mathrm{X}$ is running a deficit with country $\mathrm{Y}$, but a surplus with country $\mathrm{Z}$, the latter can be used to pay the former. Without this possibility, country $\mathrm{X}$ would have to reduce its imports from country Y and aggregate trade would shrink. Current account convertibility, with trade denominated in a fully convertible currency, also achieves multilateral clearing. Country $\mathrm{X}$ is free to use the dollars it earned from country $\mathrm{Z}$ to pay country $\mathrm{Y}$. Therefore a clearing union adds value when there is shortage of a hard currency, since netting of trade reduces hard currency payments required. Even inconvertible currencies can participate since countries agree on a common unit of account. Other ways in which a clearing union differs from convertibility is that it encourages trade among the members of a union, while under decentralized convertibility there is nothing to especially favour trade in the region. This role becomes important when markets and information are not perfect and various distortions exist that may discourage trade relations as in the SAARC region. Repeated interactions, in a region where there are few other such, and regular monitoring under centralized clearing improve information and trust. They may have contributed to some of the observed convergence in macroeconomic policies in the region.

The common unit in which ACU accounts are held and the instrument denominated for payment through the clearing facility is the "Asian Monetary Unit" (AMU). In 1996 this was switched over to the ACU dollar equivalent in value to one US\$. The ACU euro, equivalent in value to one Euro, was added from January 1, 2009. Traders could invoice their documents in hard currencies, make and receive payments in these, through member country commercial banks who could open nostro accounts in ACU dollars and ACU euros. Central banks would fund as well as absorb excess liquidity from these accounts.

These changes were motivated by the post-liberalization capital inflow driven relaxation of foreign exchange constraints, and as the easiest way to take advantage of the technological progress markets had made. Using SWIFT and foreign correspondent banks, transactions could be settled faster at real time rates reflecting the market values of member country currencies. Participants could avail facilities like forward cover for transactions, and pre-shipment and post-shipment credit 
denominated in foreign currencies. But subject to the creditor's consent, payments could also be made in its currency.

Moreover, exchange rates were not fully market determined. Possibilities of manipulation, and arbitrary and volatile movements during the settlement period, also motivated the move away from local currencies. Figure 1 shows the fall, fluctuations, and rise in the share of hard currency transactions in the ACU. Without a large expansion of intra-regional trade, settlement in hard currencies offered greater freedoms and options with less forced tie-in of trade.

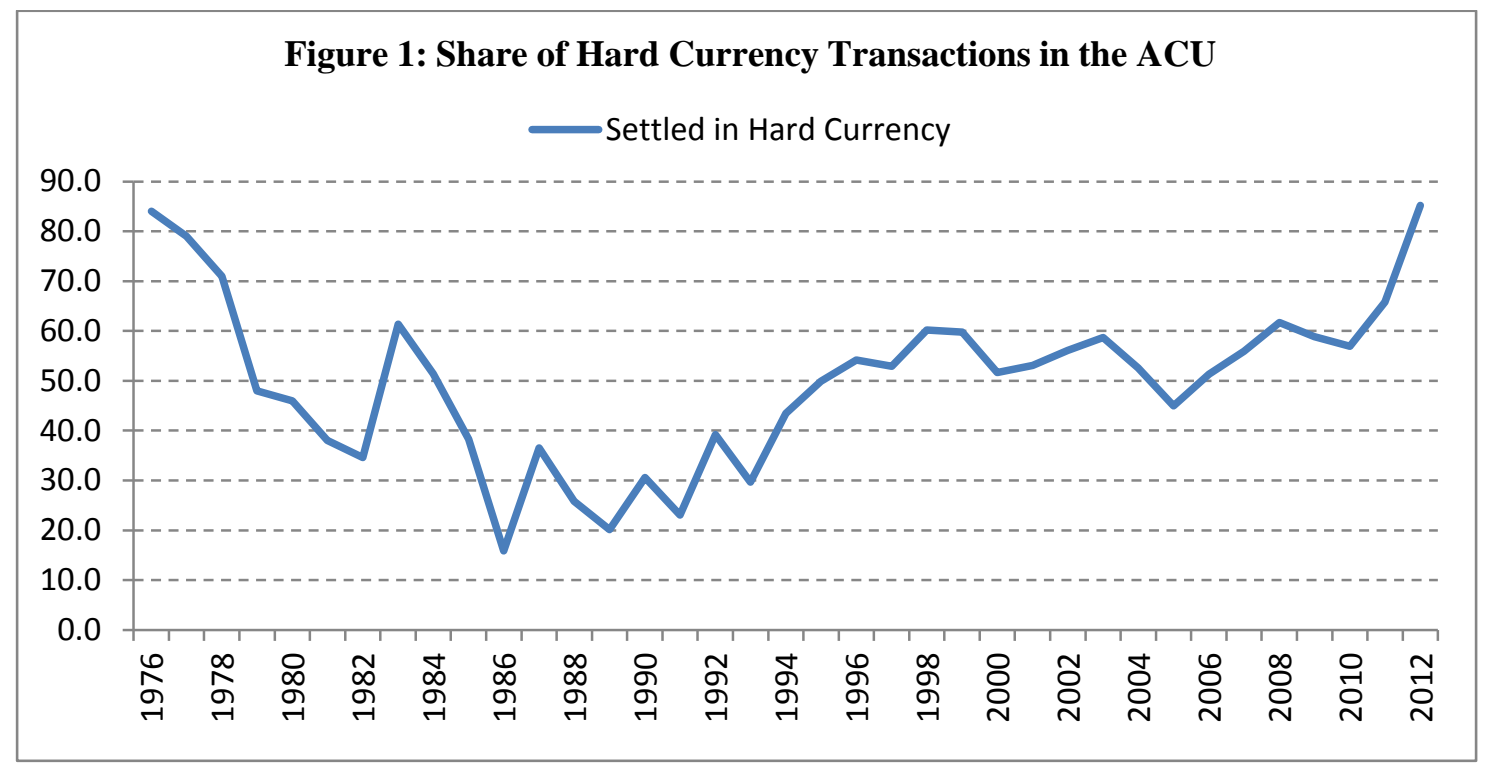

Source: ACU annual report 2012

Figure 2 shows a steady and then a sharp rise in transactions channeled through the ACU mechanism over 2002-12. ACU transactions rose because of higher regional growth after 2002, rather than the adoption of the ACU dollar. The dollar was adopted in 1996, but ACU transactions really grew over 2002-2008. Growth rates were also consistently positive over the other high growth period of 1994-96 (Figure 3).

The share of the transactions cleared in the system using netting fell from the peak of 84.1 per cent reached in 1986 , to 14.8 per cent in 2011 . The widening gap between the two lines in Figure 2 also indicates the fall in netting in the high growth period. The greater use of hard currency was correlated with a fall in netting - average netting share was 56 and 45.5 pre- and post-1992. The fall in netting share in the high growth 
period may also have reflected an asymmetric pattern of trade across countries in the region $^{5}$.

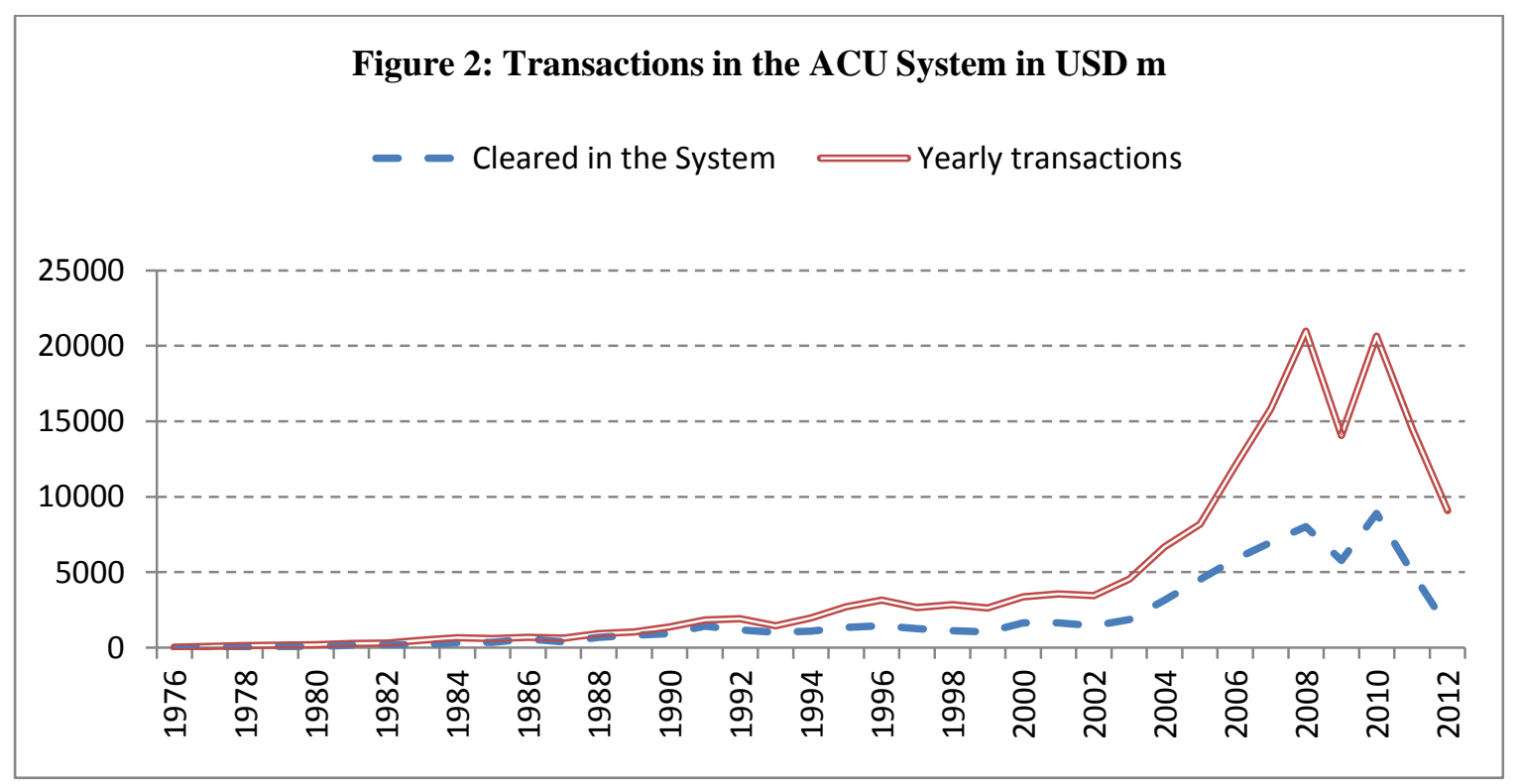

Source: ACU annual report 2012

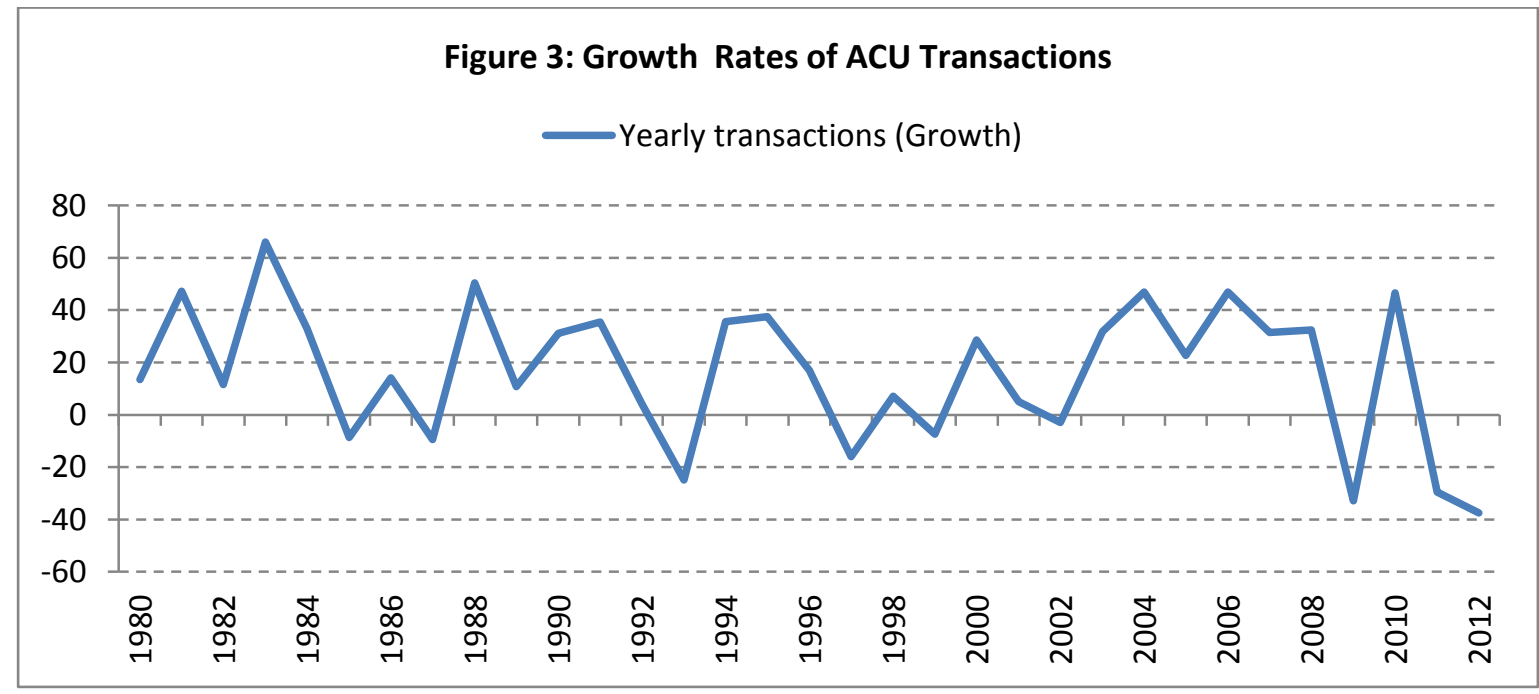

Source: ACU annual report 2012

Table 1 shows aspects of ACU performance over time. The share of one-way ACU transactions as a percentage of total regional exports rose steadily, reaching levels of 70 per cent and above over 1990-2008 (column 1), suggesting the ACU did offer

\footnotetext{
${ }^{5}$ Bilateral arrangements also sometimes erode use of the ACU mechanism. For example, in 2014, trade transaction with Myanmar could be settled in any freely convertible currency, in addition to the ACU mechanism. Payments between Nepal and India and Bhutan and India, could be made out of the ACU. Goods imported from India by an importer resident in Nepal who had been permitted by the Nepal Rastra Bank to make payments in foreign exchange could be settled through ACU mechanism. Local currency settlement could bring more trade back to the ACU.
} 
conveniences for trade. One-way transactions are taken since the ratio is to exports and not to total two-way trade. Columns 2 and 3 in Table 1 show intraregional trade as a percentage of total exports and imports respectively from the region, was higher in the early 1980's, soon after the ACU was set up; had fallen by the early 1990's but had risen again by the year 2008, when ACU transactions peaked. High growth, which raised ACU transactions steeply (Figure 2), also raised intraregional trade. The combination of global financial crisis (GFC) induced slowdown and sanctions had reduced the ratio of ACU transactions sharply by 2013, although intra-regional trade slowed less than global trade, sustaining the ratios in columns 2 and 3 (Table 1$)^{6}$.

\begin{tabular}{llllll}
\hline \multicolumn{5}{c}{ Table 1: Aspects of ACU Performance (in percentages) } \\
\hline \multicolumn{7}{r}{ Year } & $\begin{array}{l}\text { One way ACU } \\
\text { transactions/intraregion } \\
\text { exports }\end{array}$ & $\begin{array}{l}\text { Intraregional } \\
\text { exports/exports } \\
\text { from region }\end{array}$ & $\begin{array}{l}\text { Intraregional } \\
\text { imports/imports } \\
\text { of region }\end{array}$ & $\begin{array}{l}\text { Exports } \\
\text { from } \\
\text { Iran/total } \\
\text { intraregional } \\
\text { exports }\end{array}$ & $\begin{array}{l}\text { India's } \\
\text { imports } \\
\text { from } \\
\text { Iran/India's } \\
\text { oil imports }\end{array}$ \\
\hline & $\mathbf{1}$ & $\mathbf{2}$ & $\mathbf{3}$ & $\mathbf{4}$ & $\mathbf{5}$ \\
\hline $\mathbf{1 9 8 1}$ & 9.7 & 15.7 & 6.7 & 64.1 & 24.9 \\
$\mathbf{1 9 9 0}$ & 70.9 & 4 & 3.1 & 41 & 1.3 \\
$\mathbf{2 0 0 8}$ & 70.4 & 8.5 & 6.8 & 48.8 & 8 \\
$\mathbf{2 0 1 3}$ & 23.6 & 8.1 & 10.3 & 30.2 & 6.6 \\
\hline
\end{tabular}

Source: Calculated from IFS trade statistics with one-way ACU transactions (column 1) from the ACU Annual report 2009 and India's oil imports (column 5) from Directorate General of Commercial Intelligence and Statistics (DGCIS).

US sanctions against Iran's nuclear program, started in 1987, were successively tightened. Iran first did not want to include oil trade in the ACU preferring hard currency payments for oil. But later it found the ACU and rupee payments a convenient way to maintain trade. Oil was imported through the ACU since 1984. The inclusion of the ACU Euro helped escape US sanctions and may have been one reason for its adoption in 2008 .

But sidestepping sanctions did not drive the rise in ACU transactions, although ACU exports are a sizeable part of Iran's exports and Iran is India's second largest crude oil supplier. Column 4 of Table 1 shows a fall in the share of exports from Iran in total regional exports. Multiple sources, therefore, drove the expansion in ACU business. Assuming that a large part of India's imports from Iran are petroleum goods (it also

\footnotetext{
${ }^{6}$ There are consistency and completeness problems with the data. Informal trade is not measured so total trade maybe higher. Correcting for this will lower the share of trade through the ACU. But the informal trade also implies trade within the ACU can rise substantially if the ACU were able to attract it.
} 
imports dry fruits), we calculate India's imports from Iran as a percentage of India's total oil imports. Again this has fallen from its value in the eighties although it rose from a low in the nineties, and to 8 per cent at the 2008 peak, before falling marginally again (Column 5). So the ACU did not lead to over-dependence on Iranian oil imports. The trade with Iran was fully UN compliant since neither the UN nor the European Union banned oil imports from Iran.

India's oil trade went out of the ACU again in September 2010 following the toughest sanctions passed in June 2010, included penalties for international banks doing business with Iran's Islamic Revolutionary Guard. But as 2013 elections in Iran threw up a moderate leader US-Iran talks revived. With the 2015 agreement Iran trade may come back in the ACU as sanctions end.

\section{ACU: POTENTIAL CONTRIBUTIONS}

The ACU demonstrated its utility by saving scare hard currency in the early years. But this function was lost when it shifted to hard currency settlement. But there is a case now for encouraging local currency use again, not to conserve reserves as was the initial motive, but to build competitive regional payments systems, promote Asian financial integration, and provide countervailing power to the volatile dollar. Regional payment systems can protect against global instability, contribute to maintaining and enhancing regional cooperation, and help develop local financial institutions.

\section{IV.1. Arguments for the Use of Local Currencies}

The economizing-on-reserves function of the ACU continues to be important especially for the smaller countries. Netting benefits would rise with the use of local currency. Local currency use frees their hard currency resources for trade with the rest of the world, thus tending to increase trade. Some CBs may not have hard currency and may take time to arrange it. Use of local currency and liquidity would also reduce this problem. More extensive membership would strengthen the case for local currency use.

Competition in currencies of settlement and invoicing offers better options to users. When firms set prices in foreign markets, they face the choice between invoicing in their own country's currency, importer's currency, or in reserve currency. Invoicing in 
local currency reduces pass through of changes in exchange rates, and hence lowers its inflationary impact. This option, and its macroeconomic benefits, is less likely if hard currency trade settlement is imposed through the ACU. Since commodity imports such as oil tend to be priced in dollars, dollar volatility creates more pass through, which raises inflation.

Since the majority of import-export transactions between any two countries are denominated in US dollars, they are usually settled through correspondent banks in the US. This is what gives US regulations authority over banks all over the world ${ }^{7}$. The infrastructure that supports trade includes foreign trade financing instruments, and correspondent banking relationships between countries in the region. Through correspondent banking a bank can serve its clients without having to set up a branch in another country. One reason the ACU dollar was adopted as the unit of account was to enable use of these more efficient payment mechanisms. But as local payment mechanisms improve, similar equally efficient but cheaper services become possible through local area banks in regional currencies. This can compete with the continuing option to denominate trade in US\$. Real time settlement reduces currency and market risk, but easy access to liquidity is required for it. Expanded regional swap lines can contribute towards maintaining such liquidity.

A precondition for payments and settlements to be denominated in local currencies is that exchange and interest rates must not deviate too much across countries, otherwise countries holding a depreciating currency paying a low interest rate would lose. A possible solution facilitated by modern payment systems is to use hard currencies as the unit of account but settle in local currency.

In mature markets with full current account convertibility and a full float the rationale for a clearing union no longer exists, but good payment systems continue to be an asset. CBs have to initially play an active role, perhaps through institutions like the $\mathrm{ACU}$, to overcome externalities that favour AE payment systems, in order to establish competitive regional payment systems.

\footnotetext{
${ }^{7}$ In 2014 a French Bank, BNP Paribas, was fined a record 8.9 million US\$, for violating US regulatory sanctions by enabling transactions for Iran, Sudan and Cuba over 2004-12, although it was not in violation of French or UN law.
} 


\section{IV.2. ACU and Financial Aspects of Regional Integration}

South Asia has very little integration with Asian swap initiatives, and very limited own initiatives. India has offered a swap line for temporary trade credit, even as it has initiated a bilateral swap arrangement with Japan. Current South Asian swap lines, while useful to maintain short-term trade, are inadequate for a liquidity crisis, or longer-term trade financing, despite India's offer. Swap lines need to be formalized and institutionalized, with appropriate safeguards, so that they offer first, anti-crisis support divided into (a) liquidity and (b) trade support, and second longer-term trade credit. This would both support trade and reduce the need for precautionary reserve hoarding.

The existence of a liquidity backstop reassures markets even if it is not used. It complements reserves while saving the cost of holding reserves. If it is not used the interest cost is not incurred, while utility is derived just from the existence of the swap. The credit may contribute more to facilitating trade even in the absence of a crisis, if it is cheaper. Institutions for multilateral monitoring can lower the cost of credit. A multilateral monitoring institution, which is sufficiently context sensitive, can improve policies without imposing harsh arbitrary measures. So attaching the new facility, with suitable precautionary mechanisms and extensions, as part of the ACU may reduce its cost. But this would require a change in the ACU constitution.

ACU swap lines are at present limited only to the settlement cycle. If modern payment structures are integrated with the ACU, pre-funding of individual transactions will raise liquidity requirements. Such liquidity can be provided for regional currency settlements, while ACU swap lines are also redesigned to fulfill crisis-time liquidity and short-term trade credit. Given possibilities of real time settlement its two month settlement cycle is archaic, but gives benefits of netting that save reserves. While the 2-month cycle may continue at the cross CB level thus aiding aggregate balance of payment funding, faster RTGS-based settlement or ACH-based netting can be provided across regional banks and their customers, if the regional currency option is selected. Lower transaction costs can then support increasing use of local currencies in trade. 
As the ACU evolves towards a payments union with credits, so countries can reap full dynamic gains from trade with longer-term credits to finance intra-union deficits, suitable mechanisms are required to prevent any country from turning into a persistent debtor. Incentives or penalties can induce repayment of loans. These could include fixed quotas and penalties as are currently there in the ACU, and faster escalation of hard currency payments for creditors than for debtors, to ensure that creditors are not left with unusable inconvertible currencies of persistent debtors. A country would immediately exhaust its quota if permissive policies created a monetary overhang. Countries with persistent deficits would hit credit ceilings and additional credit would not be available or be dependent on stringent conditions set by the Board. Since credit is a transfer from creditors to debtors or to those furthest from stabilization, creditors may need to be compensated. Extensive soft credits would increase the temptation to inflate. So the ACU would have to have strong procedures for monitoring compliance and imposing sanctions. Macroeconomic stabilization is a precondition for such an arrangement to work.

The large intraregional Asian trade could benefit from financing within the region. Trade integration in the region is much higher than financial integration. Steps are being taken towards the latter since the East Asian currency crises of the late nineties, with the GFC keeping it going. Pending meaningful reform in the global financial architecture, and given dangers from volatile and poorly regulated capital flows, regional initiatives provide alternatives and may help ensure more symmetric adjustment.

Asia's large foreign exchange reserves are invested in AE bonds and a large share of household savings in real estate or gold. A well-developed bond market would help these funds flow to infrastructure investments. The ADB is working to establish an infrastructure bond fund to mobilize regional savings through local currency bonds, to promote more stable funding from within the region. One of the Working Groups of the Asian Bond Market Initiative has the explicit aim to reduce regional foreign exchange settlement risks and improve regional payment/ settlement systems. These facilities, along with higher growth in the region, and expansion of physical infrastructure, could reinvigorate trade along the historical old silk route. Adopting new technologies and organization in South Asia, would aid convergence in local 
standards and financial systems with eventual participation in larger Asian initiatives for Asian regional financial integration.

There is lock-in into advanced systems and developed market currencies so institutional mechanisms are required to kick start viable alternatives. US payment systems lag behind those in Europe. This suggests public initiatives have a major role in upgrading systems. It may be helpful for the process if a formal MOU is signed between the SAARC Payment Council (SPC) and the $\mathrm{ACU}^{8}$. More regular interactions as part of the SPI (SAARC Payment Initiative) and SPC will help spread best practices.

\section{IV.3. Potential ACU Enhancements}

Advances in payment systems can be used to simplify administrative procedures and reduce costs. In India ${ }^{9}$ at present (RBI, 2010), only Authorized Dealer Category-I banks are permitted to open ACU dollar and ACU Euro accounts. These have to be kept distinct from other US\$ and Euro accounts, but the settlement process through correspondent banks is the same as for normal foreign exchange transactions. The RBI funds an Indian Bank's ACU account abroad through the RBI's accounts with the Federal Reserve Bank of New York, New York, and the Deutsche Bundesbank, Frankfurt. CBs settle spillovers in either direction, through the ACU, thus reducing multiple transactions. Funding or absorption of AMU's by the CBs requires the commercial banks to make available the equivalent amount of US\$ or Euro to the CB. The CB has the option to make the payment in local currency. The reference exchange rate is the SDR cross-rate quoted by the International Monetary Fund on a daily basis.

Delays occur partly because of time differences as ACU transactions go over the three dashed loops in Figure 4: first agent and commercial banks, then banks and CBs and their foreign bank accounts. It is possible to simplify procedures.

\footnotetext{
${ }^{8}$ I thank an anonymous referee of the UNESCAP working paper series for this point.

${ }^{9}$ This section and the analysis of performance gained from conversations with Shyamala Gopinath, Deputy Governor, and the Officer in charge of the ACU, Vijay Singh Shekhawat, Deputy General Manager, Back Office and Accounts, Department of External Investments and Operations.
} 


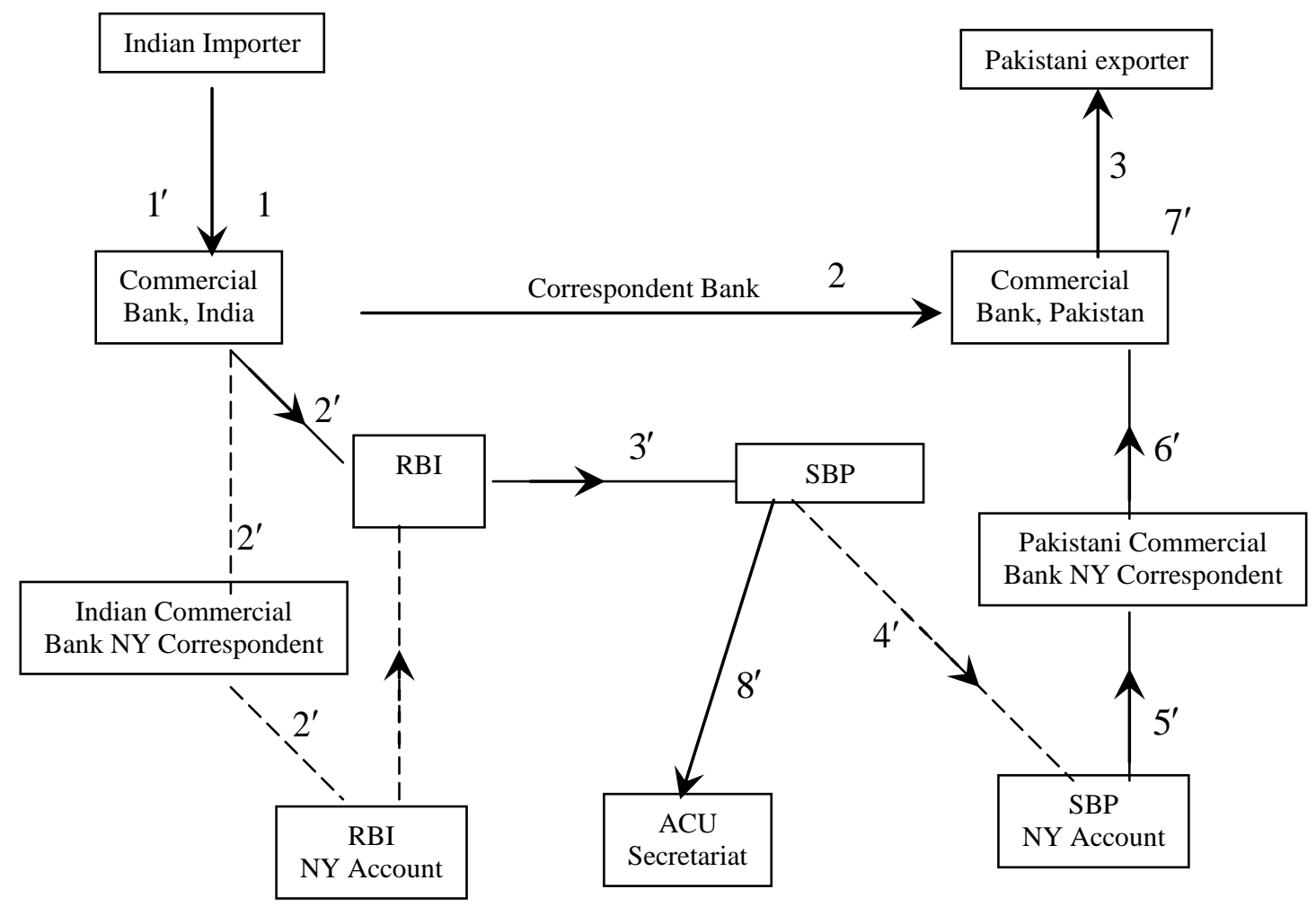

Figure 4: Transactions in the ACU

Source: Author

Use of local currency and real time facilitation between local banks and the RBI would cut the bottom two loops in Figure 3, reduce pass through time, and settlement period interest ${ }^{10}$, since it would no longer be necessary to cut across time zones ${ }^{11}$. Saving excessive cross border transactions, corresponding bank charges, and cutting float would all reduce costs. The settlement systems to be set-up could be outsourced to private providers who offer the best price quality pair, ${ }^{12}$ thus taking advantage of being a late starter to leap frog to the latest technologies. But leadership and participation would continue to be required from CBs.

\footnotetext{
${ }^{10}$ The RBI can also route its ACU hard currency transactions through correspondent banks in Hong Kong rather than New York. Mr. K.C. Chakrabarty, then RBI Deputy Governor, made this point. ${ }^{11}$ In $2011 \mathrm{Mr}$. Shekhawat mentioned the RBI was working on a project to explore this option. The settlement cycle could be decreased to 7 days from 2 months. But this is regarded as decreasing netting advantage.

${ }^{12}$ Some Asian commercial banks have outsourced to get the best core banking solutions. Compared to these, systems of MNC banks, which are a patchwork of older systems built in-house, are very slow.
} 
Procedures would have to be suitably changed, to combine maximum flexibility and speed at the level of individual transactions while advantages of netting may be retained between CBs. RTGS could be implemented across banks and between a bank and its CB, with NEFT or RTGS as applicable, between a bank and its retail customer. Local correspondent banks can be developed and domestic liquidity used even as ACU accounts are maintained separately. Enhanced data management abilities will facilitate this. The South Asian region at present is totally dependent on foreign correspondent banks and has zero CB settlement accounts, unlike AEs. Cross border settlement delays are also high in this region, exceeding 24 hours. Diversity and competition can help change this.

In EMs commercial banks dominate remittance markets although many AEs are opening them to non-bank remittance service providers to increase competition. Disproportionately high capital requirements are also a potential barrier to market entry. The ACU could offer some competition.

Moreover, path dependence on a regime of controls implies that transaction costs are higher than necessary, not only in payment systems but also other export-import related procedures, especially for smaller firms, for whom banks are less accommodative. For example, in 2014 for export by road an exporter had to submit one of five different 'Bills of Export', depending on the type of duty applicable on his goods. Information such as names of the exporter and consignee, invoice number, details of packing, description of goods, quantity, FOB value, and so on was required. Other supporting documents such as copy of packing list, invoices, export contract, and letter of credit also had to be submitted and certified by officials such as custom officers and dock appraisers ${ }^{13}$. There are initiatives to simplify procedures, for example, by using more self-certification, and moving to GST. Lower transaction costs could attract some of the large illegal trade in the region, since this goes through circuitous routes that raise costs although it escapes tariffs.

\footnotetext{
${ }^{13}$ The bills are available at http://business.gov.in/importexport/procedureexport.php.
} 
Banks have to be complaint with Foreign Exchange Management Act (FEMA) regulations and procedures in opening letters of credit, negotiations of documents etc. for trades in convertible currencies. They are also not so familiar with the ACU process for transferring foreign exchange. Awareness of its advantages has to be raised even as these are increased.

More than the absence of capital account convertibility itself, it is the paperwork and procedures required to implement know-your-customer (KYC) norms that place impediments in smooth cross border flows. These, in turn are required to prevent illegal activities such as money laundering and terrorist finance. But modern payment systems provide clear electronic trails at low cost. Once the use of electronic UID numbers becomes widespread, KYC will not require physical presence, reducing the delays it causes and facilitating person-to-person transactions and the use of payment gateways not linked to banks. Since the Indian Payments Act gives the CB jurisdiction over these gateways, there is no difficulty in calling for whatever information is required from them, for random small and large transaction checks.

One of the objectives of the SPI is to assess the volume of cross border remittance payments in SAARC member countries. Remittances are quite large in the region and are classified in the current account, but the ACU is restricted to genuine trade transactions, that satisfy KYC and other procedures. As restrictions on or records of certain types of payment flows can be maintained without cumbersome controls, meetings concerns on security and sources of funds, the ACU Board, or participants in consultation with the Board, can expand permitted types of transactions. The Agreement and Procedure Rules have periodically been revised. Membership is open to the central bank, treasury or monetary authority of each regional and associate member of ESCAP.

Improvements therefore include real time flow through the system allowing faster settlement, expansion of facilities offered including better credit availability and use of local currency, types of flows allowed, and number of participants. As countries liberate different kinds of capital flows on a gradual path to capital account convertibility, a payments union can also facilitate such flows. 


\section{IV.4. Macroeconomics and the ACU}

Macroeconomic heterogeneity, divergence and volatility in rates of inflation and in exchange rates, makes both use of local currencies and provision of credit problematic. But countries in the region have largely similar trends in macroeconomic variables; there are no wide variations in macroeconomic stabilization. No country suffers from hyperinflation. The post reform period has seen considerable institutional and market development. So an evolution to a payments union with credits is possible. Credit conditional upon improved policies may motivate outlier countries to follow better polices.

The region tends to suffer from exogenous shocks to terms of trade and the current account. The ACU tends to reduce their impact, imparting some stability to regional trade. The contribution is limited, however, by its current small share in the region's total trade.

A well-functioning payment union that encourages trade can also reduce pressures for competitive devaluations to increase exports, and allow some kind of alignment of exchange rates. This is an advantage since a rapid move to a float without appropriate institutions could imply sharp fluctuations or real exchange rate undervaluation that lowers living standards. Countries in the region largely have flexible exchange rates but more explicit coordination and transparency in exchange rate regimes will help increase the use of local currencies in the ACU.

\section{CONCLUSION}

High transaction costs vitiate South Asian intra-regional trade. Good payment systems are one way of facilitating such trade. Institutions such as the ACU and fora such as SAARC finance have the additional advantage of keeping dialogue going, helping overcome historical conflicts, and achieving convergence in important dimensions.

There are arguments made against a clearing union, especially by those who believe markets are efficient. It is regarded as an artificial construct that impedes free markets, which naturally achieve multilateral clearing. But repeated financial crises have reminded us that markets do not always work well. Moreover, especially in underdeveloped regions, markets may fail to exist. In any case, a range of institutions 
is necessary to support markets. A clearing union allows trade to take place where otherwise it would have collapsed. Since regional trade is not a large part of total trade from the region, its trade distorting effects are small, if any. It can also aid regional financial integration which tends to be even lower than trade integration because of lock-in to dominant western institutions and currencies.

The ACU has been functioning at a low level, without much importance being given to it by the participant countries and central banks so that its potential is underutilized. A makeover can help the ACU ride the technology wave and fulfill new emerging needs, even while better meeting the old ones. These new needs include morphing into a good regional payment system, as part of larger Asian initiatives to provide such systems to improve regional financial integration, and contribute to revitalizing historic trade routes, even as other types of trade costs are reduced.

RTGS that allow real time settlements reduce risks from volatile currencies, and more convergence in macroeconomic policies and financial systems reduce volatilities. The alternative of registering the value at the date of the transaction, even if aggregate settlement is delayed, becomes available, encouraging the use of local currencies. Easy access to liquidity is required for real time settlement. Selecting the option of using local currencies in trade can be supported with domestic liquidity and faster RTGS or netting, thus lowering transaction costs. Further expansion in regional swap lines can contribute to maintaining liquidity in crisis times, as well as to trade credits. This will reduce vulnerability to US\$ volatility and regulatory regimes while impose more competitive discipline on the US\$.

As countries in the region move towards greater capital account convertibility, the ACU should enable more types of capital flows. Concerns about security, and discrimination between types of flows and sources are not an issue because electronic systems can provide this information without procedural delays. Changes could start with an improved real time flow through the system, streamlining of procedures, expansion of facilities offered, types of flows allowed, and number of participants. More explicit monetary coordination, more transparent exchange rate regimes, and more explicit peer macroeconomic review, would increase confidence enabling the use of local currencies. Creating deeper economic links would shift the region away 
from passions towards interests, leaving wars and conflicts behind and moving to a future of shared prosperity. Even if larger cooperation takes time to achieve, concrete projects, for which the countries can interact, can help them adjust conflicts of interest and move beyond such conflicts.

Both institutions and leadership are required for successful change. Germany and France played leading roles in the European Union's long economic integration process while Marshall Plan funds from the US financed the expansion of the EPU's functions. Faster growth in Asia, as well as oil exporters' revenue, should make funds available in South Asia. Given the current low-level equilibrium, multilateral financing may be useful to kick start the process. But country contributions build ownership, and demonstrate commitment, which would encourage investment in facilities for regional trade.

Investing more funds signals a commitment to trade, since it is a costly investment undertaken specifically for trade. It is as if governments post a bond such that there is a loss if they do not in future support trade and turn protectionist. With such a bond, private parties will be encouraged to undertake the sunk costs necessary to build trade networks. The binding agreement by the first mover allows the second mover also to pre-commit to trade. This would create a public good contributing to Asian integration. Growing regional ties need not be at the expense of other ties. Multiple friendships, alignment and engagements, based on growing domestic strengths, will make for healthier overall relationships.

\section{References}

BIS (2001). Core Principles for Systemically Important Payment Systems. Committee on Payment and Settlement Systems. January. Available at http://www.bis.org/publ/cpss43.pdf. Accessed in June 2014.

Haldane, A. G., S. Milllard and V. Saporta (2008). 'The Future of Payment Systems'. Routledge International Studies in Money and Banking, New York.

Khiaonarog, T. (2000). 'Electronic Payment Systems Developed in Thailand'. International Journal of Information Management, 20(1):59-72.

RBI (Reserve Bank of India). (2010). Memorandum of Procedure for Channeling Transactions through Asian Clearing Union. A.P. (DIR Series) Circular No.35 dated February 17. Available at 
http://rbidocs.rbi.org.in/rdocs/notification/PDFs/APIR35M170210.pdf. Accessed in June 2014.

Saqib, A. and A. Al-Jabri. (2011). Oman's National Payment Systems and their Compliance with International Standards and Practices. Journal of Internet Banking and Commerce, 16(3):1-25. December.

World Bank. (2010). Global Payment Systems Survey, 2010. Available at http://siteresources.worldbank.org/FINANCIALSECTOR/Resources/2820441260476242691/Zanza_Chimienti_GlobalPayment_Systems_Survey.pdf. Accessed on May 23, 2014.

$\begin{array}{ll}\text { ABBREVIATIONS } \\ \text { ACH } & \text { Automatic Clearing House } \\ \text { ACU } & \text { Asian Clearing Union } \\ \text { AEs } & \text { Advanced Economies } \\ \text { AMU } & \text { Asian Monetary Unit } \\ \text { CB } & \text { Central Bank } \\ \text { CMA } & \text { Common Monetary Area } \\ \text { DGCIS } & \text { Directorate General of Commercial Intelligence and Statistics } \\ \text { ECC } & \text { Electronic Cheque Clearing } \\ \text { EMs } & \text { Emerging Markets } \\ \text { FEMA } & \text { Foreign Exchange Management Act } \\ \text { GFC } & \text { Global Financial Crisis } \\ \text { KYC } & \text { Know Your Customer } \\ \text { NEFT } & \text { National Electronic Fund Transfer } \\ \text { PvP } & \text { Payment versus Payment } \\ \text { REPSS } & \text { Regional Payment and Settlement System } \\ \text { RTGS } & \text { Real Time Gross Settlement } \\ \text { SAARC } & \text { South Asian Association for Regional Cooperation } \\ \text { SADC } & \text { Southern African Development Community } \\ \text { SEPA } & \text { Single Euro Payments Area } \\ \text { SPC } & \text { SAARC Payment Council } \\ \text { SPI } & \text { SAARC Payment Initiative } \\ \text { STP } & \text { Straight Through Processing } \\ \text { SWIFT } & \text { Society for Worldwide Interbank Financial Telecommunication } \\ \text { UN-ESCAP } & \text { United Nations Economic and Social Commission for Asia and the } \\ & \text { Pacific } \\ & \end{array}$

